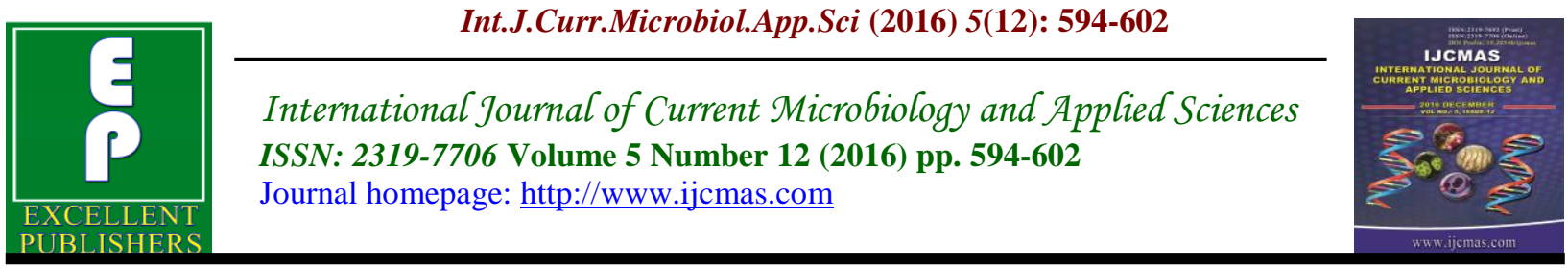

Original Research Article

http://dx.doi.org/10.20546/ijcmas.2016.512.064

\title{
In-vitro Antimicrobial Screening of Dendrophthoe falcata (L.F.) Ettingsh
}

\author{
Anita Jain $^{1 *}$ and Mahima Sharma ${ }^{2}$ \\ ${ }^{1}$ Department of Botany, Vidya Bhawan Rural Institute, Udaipur- 313001(Rajasthan), India \\ ${ }^{2}$ Pacific Academy of Higher Education and Research University, Udaipur, Rajasthan, India \\ *Corresponding author
}

\section{A B S T R A C T}

Keywords

Antimicrobial

screening,

Phytochemical,

Dendrophthoe

falcata, Aravalli

hills, Rajasthan.

\section{Article Info}

Accepted:

18 November 2016

Available Online:

10 December 2016
Bioassay (petroleum ether, chloroform, ethyl acetate and methanol) of various leaf and stem extracts of Dendrophthoe falcata (L.F.) Ettingsh were investigated for an in vitro antimicrobial activity against five bacteria: Escherichia coli, Staphylococcus aureus, Klebsiella pneumoniae, Pseudomonas aeruginosa and Streptococcus pneumoniae and two fungi Candida albicans and Aspergillus niger. Among all the extracts of leaf and stem, methanolic and ethyl acetate shows good sensitivity against all the tested organisms. Furthermore, among fungi studied, methanolic extract of leaf showed higher antifungal activity against $A$. niger while in stem ethyl acetate and methanol showed moderate antifungal activity against $A$. niger. In $C$. albicans ethyl acetate extract of stem found to most active. The present investigation showed the effectiveness of crude extract of this plant against tested microorganisms.

\section{Introduction}

Dendrophthoe falcata (L.F.) Ettingsh belongs to family Loranthaceae, is an evergreen hemiparasitic plant grown on different host trees like Boswellia serrata, Mangifera indica, Ficus religiosa, Madhuca latifolia, $M$. indica and $F$. rumphii etc. (Singh and Gupta, 2013). It is also known as 'Vanda' in the Indian Ayurvedic system of medicine and 'Vrksadani' and 'Vrksaruha' in 'Sanskrit'. It is indigenous to tropical regions especially in India, Srilanka, Thailand, China, Australia, Bangladesh, Malaysia and Myanmar (Manthri et al., 2011).

Whole plant and part/s like bark, Leaves, flower, stem and fruits possesses medicinal potential and indigenous communities use it for treatment of various human and animal ailments like rheumatic complaints (Md. Shahidullah, 2009; Shanavaskhan, et al., 2012), leucorrhoea (Shanavaskhan et al., 2012; Rothe, 2003), as contraceptive (Mairh et al., 2010), skin diseases (Kunwar et al., 2005; Ganasen et al., 2009), bone fracture (Kunwar et al., 2005; Partha \& Hossain, 2007), asthma (Reddy et al., 2006; Kumar et al., 2012), wound healing (Vijigiri and Sharma, 2010; Kunwar et al., 2005), for abortion (Kunwar et al., 2005; Ganasen et al., 2006; Kaur and Mehta, 2014) and schizophrenia (Mali and Bhadane, 2011). Ethnoveterinary use of this plant is also reported by Katewa \& Jain (2006), extract of 
whole plant is applied locally on uterus of cattle in volvo-vaginal-uterine prolapse. Its pharmacological activities like anti-oxidant, anti-hyperlipidaemic, anti-diabetic, diuretic and antilithiatic activity have also been studied (Tenpe et al., 2008; Pattanayak and Sunita, 2008; Aleykutty et al., 1993). The plant contains phytosterols, flavonoids, quercetin, phenolic compounds, tannin and terpins (Pattanayak and Sunita, 2008; Dashora et al., 2010) etc.

Antibacterial and antifungal screening of aerial parts of Dendrophthoe falcata was studied by Pattanayak \& Sunita (2008) while Patil et al., (2012) studied antibacterial sensitivity of different solvent of leaves of D. falcata growing on M. indica. Perusal of literature indicates that $D$. falcata, growing hemiparasitically on $B$. serrata, yet not studied for their antimicrobial potential. Thus, the present studies undertake to check antimicrobial potential of various extracts of leaves and stem of the D. falcata growing on B. serrata.

\section{Materials and Methods}

\section{Collection of plant material}

The leaves and stem of $D$. falcata growing on $B$. serrata were collected from the southern Aravalli hills of Rajasthan. The plant was identified from its morphological features as mentioned in different standard text and flora (Hooker, 1872-1897). The voucher specimen has been deposited at VBRI, Udaipur for further reference.

\section{Preparation of extracts}

Stem and leaves washed, shade dried and powdered by using a pulveriser. Coarse powders (100g of stem and 90gm of leaves) then subjected to successive extraction with organic solvents such as petroleum ether, chloroform, ethyl acetate and methanol by
Soxhlet method for $12 \mathrm{hrs}$. The extract were filtered and filtrate was concentrated to dryness under reduced pressure in rotary vacuum evaporator and stored at $4^{\circ} \mathrm{C}$. Percent extractive yield was calculated by the following formula and are listed in table1 .

Percent extractive $=$ weight of dried extract $\times 100$

Weight of dried plant material

To make stock solution of $100 \mathrm{mg} / \mathrm{ml}$ of each extract (crude drug) the appropriate amount is weighed and dissolved in DMSO. The stock solution was passed through $0.2 \mu \mathrm{m}$ pyrogesic filter to sterilize the solution and further concentrations of $50 \mathrm{mg} / \mathrm{ml}, 25$ $\mathrm{mg} / \mathrm{ml}$ and $12.5 \mathrm{mg} / \mathrm{ml}$ was made by diluting with Di Methyl Sulfoxide (DMSO).

\section{Test microorganism}

The pathological strains of test organism i.e. Escherichia coli (MTCC 118), Staphylococcus aureus (MTCC 96), Klebsiella pneumoniae (MTCC 39), Pseudomonas aeruginosa (MTCC 424) and Streptococcus pneumoniae (MTCC *655), Aspergillus niger (MTCC 281) and Candida albicans (MTCC 183) were obtained from MTCC, Chandigarh, India and again identified by standard methods of identification (Collee et al., 1996).

\section{Antimicrobial Susceptibility Testing}

\section{Well Diffusion Method}

The in vitro antimicrobial activity was determined by the agar well diffusion method (Guven et al., 2006). Cell suspensions containing $10^{6} \mathrm{CFU} / \mathrm{ml}$ cells for bacteria and yeasts and $10^{5} \mathrm{spore} / \mathrm{ml}$ of fungi were prepared and $100 \mu \mathrm{l}$ was evenly spread on the surface of the nutrient agar for bacteria and sabouraud dextrose agar medium for yeasts and fungi using glass 
spreader. The wells of $6 \mathrm{~mm}$ diameter were made at equidistant. $100 \mu \mathrm{l}$ volumes of crude extract of each concentration were dispensed into wells, the plate were incubated at $37^{\circ} \mathrm{C}$ for $24 \mathrm{hrs}$ for bacterial strains, $48 \mathrm{hrs}$ for yeasts and $72 \mathrm{hrs}$ for fungi at $28^{\circ} \mathrm{C}$. The diameter of zone of inhibition was measured. As reference antibiotic Meropanum $(5 \mu \mathrm{g} / \mathrm{ml})$ was used against all the tested bacteria and Amphoteracin-B (30 $\mu \mathrm{g} / \mathrm{ml}$ ) for yeast and fungi.

\section{Minimum inhibitory concentration (MIC)}

The estimation of MIC of the crude extracts was carried out using the method of agar well diffusion (Mohana et al., 2008; Bais et al., 2013) with some modification. Approximate amount of extract was taken from the solution of the crude drug sample $(12.5 \mathrm{mg} / \mathrm{ml})$ with DMSO and diluted it serially (1:1) with DMSO to the concentration of $0.012 \mathrm{mg} / \mathrm{ml}$. As a result, a series of the sample solution in decreasing concentration was obtained by a ratio of 0.5 (final concentration: from $6.25 \mathrm{mg} / \mathrm{ml}$ to $0.012 \mathrm{mg} / \mathrm{ml})$. In this method the least concentration of each extract showing a clear zone of inhibition was taken as the MIC. The MIC value was defined as the lowest concentration to inhibit visible growth of microbes.

\section{Preliminary phytochemical screening}

All the extracts of leaves and stem of $D$. falcata were screened for various secondary metabolites such as tannins, alkaloids, phenols, steroids, flavonoids, and saponins using standard methodology (Panday \& Tripathi, 2014).

\section{Results and Discussion}

In-vitro antimicrobial screening of various extracts of leaves and stem of D. falcata, was shown in Table-2 and 3. The antimicrobial activity was dose-dependent because activity at $100 \mathrm{mg} / \mathrm{ml}$ more than other concentrations against the entire tested microorganism. As shown in Table-2, the extract form the D. falcata leaves and stem displayed antimicrobial activity against the tested bacterial strains, with the diameter of zone of inhibition ranging between $10 \mathrm{~mm}$ to $20 \mathrm{~mm}$. Among the all extract of leaf, both methanol and ethyl acetate extract produce $20 \pm 0.0 \mathrm{~mm}$ zone of inhibition against $S$. pneumoniae and methanol extract of leaves also produce $17 \pm 0.0 \mathrm{~mm}$ zone of inhibition against $K$. pneumoniae while in stem, ethyl acetate extract showed higher antibacterial activity against $P$. aeruginosa $(20 \pm 0.0)$ and S. pneumoniae $(19 \pm 0.0)$.

Furthermore, among fungi studied (Table-3), methanolic extract of leaf showed higher antifungal activity against $A$. niger with a zone of inhibition $22 \pm 0.0 \mathrm{~mm}$ while in stem ethyl acetate and methanol showed moderate antifungal activity against $A$. niger with a zone of inhibition $22 \pm 0.0$ and $21 \pm$ $0.0 \mathrm{~mm}$ respectively. In $C$. albicans ethyl acetate extract of stem found to most active with a zone of inhibition $11.33 \pm 0.57$.

The MIC of ethyl acetate extract against the entire tested microorganism was observed to be a range of 0.781 to $6.25 \mathrm{mg} / \mathrm{ml}$ (Table-4). Table-1 shows percentage extractive values of D. falcata leaf and stem extracts obtained with various solvents. Ethyl acetate extract gave maximum percent extractive value.

A preliminary screening was done to check the presence of various phytoconstituents in the extracts (Table-5). It was found that chloroform extract of $D$. falcata leaf shows presence of phenols. Ethyl acetate extracts shows presence of flavonoids, phenols, steroids and saponins while methanol extracts shows presence of flavonoids, phenols, saponins and tannins. 
Table.1 Yield of extracts of leaves and stem of Dendrophthoe falcata extracted in different solvents by soxhlet apparatus

\begin{tabular}{|c|c|c|}
\hline Solvents & Leaves & stem \\
\hline Petroleum ether & $1.63 \%$ & $7.17 \%$ \\
\hline Chloroform & $2.33 \%$ & $2.12 \%$ \\
\hline Ethyl acetate & $21.32 \%$ & $17.39 \%$ \\
\hline Methanol & $1.44 \%$ & $1.66 \%$ \\
\hline
\end{tabular}

Table.2 Showing zone of inhibition of different extracts of D. falcata against bacteria

\begin{tabular}{|c|c|c|c|c|c|c|c|c|c|}
\hline \multirow{2}{*}{$\begin{array}{c}\text { Name of } \\
\text { Organisms }\end{array}$} & \multirow{3}{*}{$\begin{array}{c}\text { Cons. } \\
\text { Mg/ml }\end{array}$} & \multicolumn{8}{|c|}{ D. falcate } \\
\hline & & \multicolumn{4}{|c|}{ Leaf extracts } & \multicolumn{4}{|c|}{ Stem extracts } \\
\hline \multirow{10}{*}{$\begin{array}{c}\text { Escherichia } \\
\text { coli (MTCC } \\
118)\end{array}$} & & PE & Chlo & $\mathbf{E A}$ & Meoh & PE & Chlo & $\mathbf{E A}$ & Meoh \\
\hline & 100 & $11 \pm 0.0$ & $12 \pm 0.0$ & $13 \pm 0.0$ & $13 \pm 0.0$ & - & $12 \pm 0.0$ & $13.33 \pm 0.57$ & $12 \pm 0.0$ \\
\hline & 50 & $10 \pm 0.0$ & $11 \pm 0.0$ & $12.66 \pm 0.57$ & $11.33 \pm 0.57$ & - & $11 \pm 0.0$ & $13 \pm 0.0$ & $11.33 \pm 0.57$ \\
\hline & 25 & - & $10 \pm 0.0$ & $12.33 \pm 0.57$ & $10.33 \pm 0.57$ & - & $10.33 \pm 0.57$ & $12.66 \pm 0.57$ & $11 \pm 0.0$ \\
\hline & 12.5 & - & - & $12 \pm 0.0$ & $10 \pm 0.0$ & - & $10 \pm 0.0$ & $12 \pm 0.0$ & $10 \pm 0.0$ \\
\hline & 6.25 & & & $11.33 \pm 0.57$ & & & & $11.33 \pm 0.57$ & \\
\hline & 3.125 & & & $11 \pm 0.0$ & & & & $10.66 \pm 0.57$ & \\
\hline & 1.562 & & & $10.66 \pm 0.57$ & & & & $10.33 \pm 0.57$ & \\
\hline & 0.781 & & & $10 \pm 0.0$ & & & & $10 \pm 0.0$ & \\
\hline & 0.390 & & & - & & & & - & \\
\hline \multirow{6}{*}{$\begin{array}{c}\text { Klebsiella } \\
\text { pneumoniae } \\
\text { (MTCC 39) }\end{array}$} & 100 & - & $12.33 \pm 0.57$ & $16.33 \pm 0.57$ & $17 \pm 0.0$ & - & - & $17 \pm 0.0$ & $15 \pm 0.0$ \\
\hline & 50 & - & $12 \pm 0.0$ & $15 \pm 0.0$ & $15.66 \pm 0.57$ & - & - & $16 \pm 0.0$ & $14.33 \pm 0.57$ \\
\hline & 25 & - & $11 \pm 0.0$ & $13 \pm 0.0$ & $13 \pm 0.0$ & - & - & $15 \pm 0.0$ & $12.66 \pm 0.57$ \\
\hline & 12.5 & - & $10 \pm 0.0$ & $12 \pm 0.0$ & $12 \pm 0.0$ & - & - & $13 \pm 0.0$ & $11 \pm 0.0$ \\
\hline & 6.25 & & & $11 \pm 0.0$ & & & & $12 \pm 0.0$ & \\
\hline & 3.125 & & & $10 \pm 0.0$ & & & & $11 \pm 0.0$ & \\
\hline
\end{tabular}




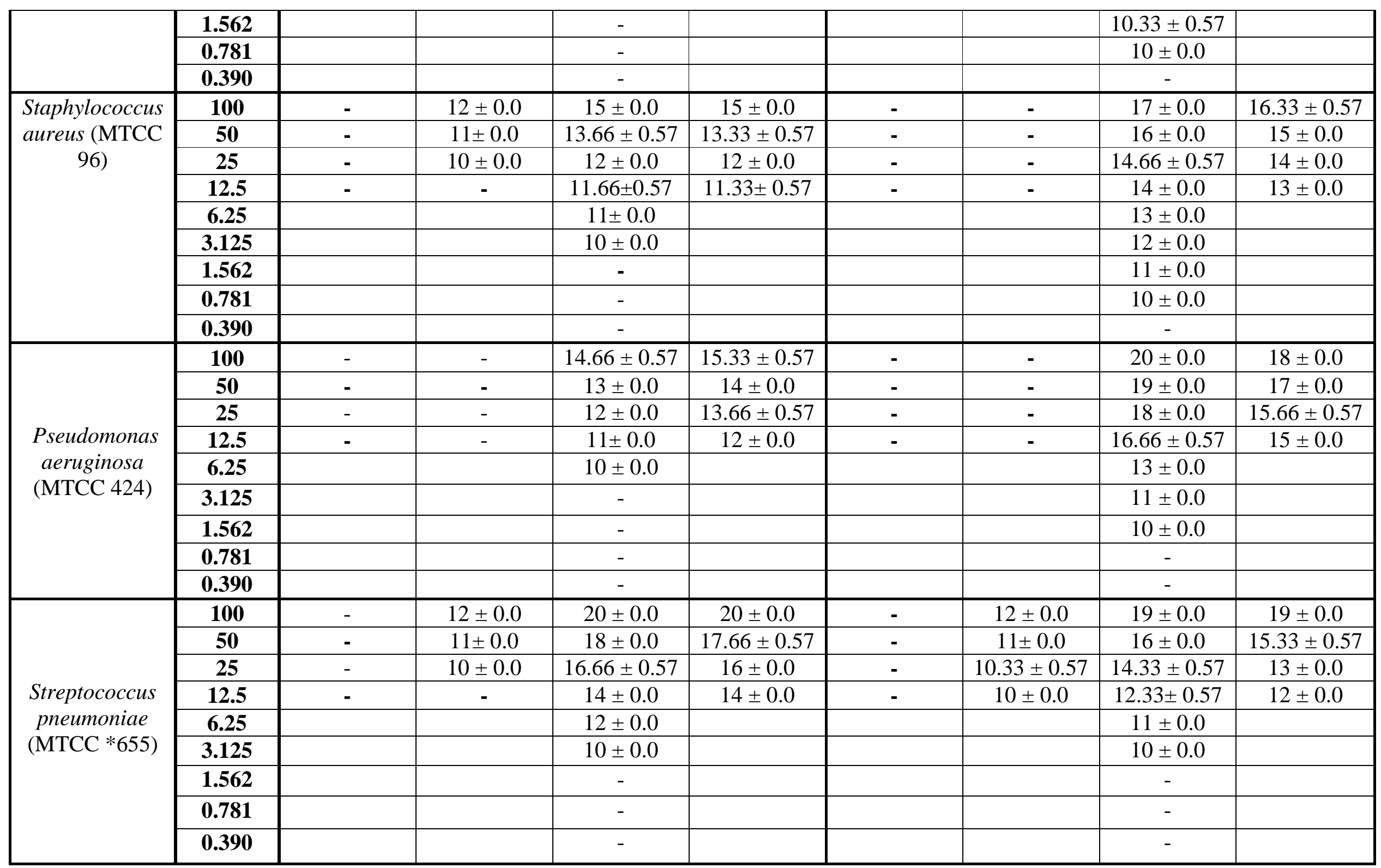

Abbreviations: PE- Petroleum ether, Chlo- Chloroform, EA- Ethyl acetate, MeOH- Methanol 
Table.3 Showing zone of inhibition of different extracts of D. falcata against fungi

\begin{tabular}{|c|c|c|c|c|c|c|c|c|c|}
\hline \multirow{2}{*}{$\begin{array}{c}\text { Name of } \\
\text { Organisms }\end{array}$} & \multirow{2}{*}{$\begin{array}{c}\text { Cons. } \\
\text { Mg/ml }\end{array}$} & \multicolumn{8}{|c|}{ D. falcate } \\
\hline & & \multicolumn{4}{|c|}{ Leaf extract } & \multicolumn{4}{|c|}{ Stem extract } \\
\hline \multirow{10}{*}{$\begin{array}{c}\text { Aspergillus } \\
\text { niger } \\
\text { (MTCC 281) }\end{array}$} & & $\mathbf{P E}$ & Chlo & $\mathbf{E A}$ & Meoh & $\mathbf{P E}$ & Chlo & E A & Meoh \\
\hline & 100 & $10 \pm 0.0$ & $16.33 \pm 0.57$ & $19 \pm 0.0$ & $22 \pm 0.0$ & $12 \pm 0.0$ & $13 \pm 0.0$ & $22 \pm 0.0$ & $21 \pm 0.0$ \\
\hline & 50 & - & $16 \pm 0.0$ & $17.33 \pm 0.57$ & $19 \pm 0.0$ & $10 \pm 0.0$ & $12 \pm 0.0$ & $20 \pm 0.0$ & $19 \pm 0.0$ \\
\hline & 25 & - & $13 \pm 0.0$ & $17 \pm 0.0$ & $16 \pm 0.0$ & - & $10 \pm 0.0$ & $18.66 \pm 0.57$ & $18 \pm 0.0$ \\
\hline & 12.5 & - & $11.66 \pm 0.57$ & $16 \pm 0.0$ & $16 \pm 0.0$ & - & - & $17 \pm 0.0$ & $16.66 \pm 0.57$ \\
\hline & 6.25 & & & $15 \pm 0.0$ & & & & $16 \pm 0.0$ & \\
\hline & 3.125 & & & $13 \pm 0.0$ & & & & $15 \pm 0.0$ & \\
\hline & 1.562 & & & $11 \pm 0.0$ & & & & $12 \pm 0.0$ & \\
\hline & 0.781 & & & - & & & & $11 \pm 0.0$ & \\
\hline & 0.390 & & & - & & & & - & \\
\hline \multirow{9}{*}{$\begin{array}{c}\text { Candida } \\
\text { albicans } \\
\text { (MTCC 183) }\end{array}$} & 100 & - & - & - & - & - & $10.33 \pm 0.57$ & $11.33 \pm 0.57$ & - \\
\hline & 50 & - & - & - & - & - & - & $10 \pm 0.0$ & - \\
\hline & 25 & - & - & - & - & - & - & - & - \\
\hline & 12.5 & - & - & - & - & - & - & - & - \\
\hline & 6.25 & & & - & & & & - & \\
\hline & 3.125 & & & - & & & & - & \\
\hline & 1.562 & & & - & & & & - & \\
\hline & 0.781 & & & - & & & & - & \\
\hline & 0.390 & & & - & & & & - & \\
\hline
\end{tabular}

Table.4 Antimicrobial activity of ethyl acetate extract of different plant part of D. falcata in term of MIC.

\begin{tabular}{|c|c|c|}
\hline \multirow{2}{*}{ Name of organisms } & \multicolumn{2}{|c|}{ E A extract D. falcata } \\
\cline { 2 - 3 } & Leaves & Stem \\
\cline { 2 - 3 } & MIC mg/ml & MIC mg/ml \\
\hline Escherichia coli (MTCC 118) & 0.781 & 0.781 \\
\hline Klebsiella pneumoniae (MTCC 39) & 3.125 & 0.781 \\
\hline Staphylococcus aureus (MTCC 96) & 3.125 & 0.781 \\
\hline Pseudomonas aeruginosa (MTCC 424) & 6.25 & 1.562 \\
\hline Streptococcus pneumoniae (MTCC *655) & 3.125 & 3.125 \\
\hline Candida albicans (MTCC 183) & - & - \\
\hline Aspergillus niger (MTCC 281) & 1.562 & 0.781 \\
\hline
\end{tabular}


Table.5 Qualitative examination of secondary metabolites of extracts of Dendrophthoe falcata leaves and stem

\begin{tabular}{|c|c|c|c|c|c|c|c|c|c|}
\hline \multirow{2}{*}{$\begin{array}{c}\text { S. } \\
\text { No. }\end{array}$} & \multirow[t]{2}{*}{ Phytochemicals } & \multicolumn{2}{|c|}{ Petroleum ether extract } & \multicolumn{2}{|c|}{ Chloroform extract } & \multicolumn{2}{|c|}{ Ethyl acetate extract } & \multicolumn{2}{|c|}{ Methanol extract } \\
\hline & & Leaves & Stem & Leaves & Stem & Leaves & Stem & Leaves & Stem \\
\hline 1. & Alkaloids & - & - & - & - & - & - & - & - \\
\hline 2. & Flavonoids & - & - & - & - & ++ & - & + & - \\
\hline 3. & Steroids & - & - & - & - & + & - & - & - \\
\hline 4. & Phenols & - & - & + & - & ++ & ++ & ++ & + \\
\hline 5. & Tannins & - & - & - & - & - & + & - & ++ \\
\hline 6. & Saponins & - & - & - & - & ++ & ++ & + & + \\
\hline
\end{tabular}


Patil et al., (2012) studied antimicrobial sensitivity of different solvent extracts of leaves of $D$. falcata growing on $M$. indica at the concentration of $200 \mathrm{mg} / \mathrm{ml}$. Different extracts of leaves displayed antimicrobial activity against the tested bacterial ( $S$. aureus, $E$. coli and $P$. aeruginosa) and fungal (A. niger and $C$. albicans) strains with the diameter of zone of inhibition ranging between $10 \mathrm{~mm}$ to $14 \mathrm{~mm}$ while the different extract of leaves of $D$. falcata growing on $B$. serrata found to be most active against same tested bacterial and fungal strains with zone of inhibition ranging between $10 \mathrm{~mm}$ to $22 \mathrm{~mm}$ at the concentration of $100 \mathrm{mg} / \mathrm{ml}$. The present finding demonstrate that $D$. falcata that growing on $B$. serrata shows better antimicrobial activity than growing on $M$. indica.

The present study demonstrate that, plant extracts in ethyl acetate and methanol provided a good zone of inhibition while other two extracts were found to be less active against the tested organisms (Table 2 and 3). The present investigation clearly establishes the antimicrobial potential of the plant and suggests the need to further exploit in the management of microbial diseases caused by these bacteria in humans. From the result obtained it supports the folkloric usages of D. falcata as a therapeutic agent. Further phytochemical investigation suggests that all the extract contain certain constituents with antimicrobial properties that can be used as antimicrobial agents in new drug for the therapy of infectious diseases caused by pathogen.

\section{References}

Aleykutty, N.A., Srinivasan, K.K., Gundu, R. P., Udupa, A. C., Keshavmurti, 1993. Diuretic and antilithiatic activity of Dendrophthoe falcata. Fitoterapia, 64: 325-331.
Bais, Y., Chaudhari, S.B., Belani, S., Umarkar, A.R. 2013. Evaluation of antimicrobial activity of plant leaf Argemone Mexicana. Inter. J. Pharm. and Biol. Sci., 3(1): 41-45.

Collee, J. G., Miles, R. S., Watt, B. 1996. Test for identification of bacteria. In MacKie \& McCartney's Practical Medical Microbiology. 14: 131-149.

Dashora, N., Agrawal, R., Sodde, V., Prabhu, K.S., Lobo, R. 2010. Pharmacognostical evaluation of Dendrophthoe falcata. J. Phar. Res., 3(5):971-974.

Ganasen, S, Ponnuchamy, M., Kesavan, L., Selvaraj, 2009. Floristic composition and parasites on the selected sacred groves of Pallapatty village (Reserved forest), Tamil Nadu. Ind. J. Tradi. Know., 8(2): 154-162.

Ganasen, S., Venkateshan, G., Banumathy, N. 2006. Medicinal plants used by ethnic groups Thottianaickans of Semmalai hills (reserved forest), Tiruchirappalli district, Tamil Nadu. Ind.. J. Tradi. Know., 5(2). 245-252.

Guven, K., Yucel, E., Cetinta, F. 2006. Antimicrobial activities of fruits of Crataegus and Pyrus species. Pharmaceu. Bio., 44(2): 79-83.

Hooker, J.D. 1872-1897. Flora of British India, Reeve \& Co., NR Ash food, Kent., Vol.1-7.

Katewa, S. S., Jain, A. 2006. Traditional folk herbal medicines. Apex Publishing House, Udaipur.

Kaur, H., Mehta, R. 2014. Medicinal plants as a source of alternative medicine in birth control: a review. World J. Pharma. Res., 3(10):306-322.

Kumar, Y. V., Sekhar, P. C., lakshmi, B. S., Harasreeramulu, S. 2012. Folk Medicinal plants used in the treatment of asthma in polavaram forest area, West Godavari district, A. P., India. Int. J. Ayru. Her. Med., 2(6):947-953.

Kunwar, R. M., Adhikari, N., Devkota, M. P. 2005. Indigenous use of mistletoes in tropical and temperate region of Nepal. Banko Janakari, 15(2):38-42. 
Mairh, A.K., Mishra, P.K., Kumar, J., Mairh, A. 2010. Traditional botanical wisdom of Birhore tribes of Jharkhand. Ind. J. Tradi. Know., 9(3): 467-470.

Mali, P.Y., Bhadane, V. V. 2011. Ethnomedicinal wisdom of tribals of Aurangabad district (M.S.), India. Ind. J. Nat. Por. Res., 2(1): 102-109.

Manthri, S., Kota, C.S., Talluri, M. 2011. Pharmacognostic, phytochemical and pharmacological review of Dendrophthoe falcata. J. Phyto. Phytopharma., 3 (3): 18-25.

Md Shahidullah, Al-Mujahidee, Md Uddin, S.M.N., Md H.S., Hanif, A., Bari, S, Md., R. 2009. Medicinal plants of the Santal Tribe residing in Rajshahi district, Bangladesh. American-Eurasian J. Sustainable Agri., 3(2): 220-226.

Mohana, D.C., Satish, S., Raveesha, K.A. 2008. Antibacterial evaluation of some plant extracts against some human pathogenic bacteria. Advs. in Biolo. Res., 2 (3-4): 49-55.

Pandey, A., Tripathi, S. 2014. Concept of standardization, extraction and pre phytochemical screening strategies for herbal drug. J. Pharmacognosy \& Phytochem., 2 (5): 115-119.

Partha, P., Hossain, A.B.M. E. 2007. Ethnobotanical investigation into the mandi ethnic community in Bangladesh. Bangla. J. Plant Taxon., 14(2): 129-145.

Patil, S.H., Patil, S.V., Jadhav, R.B., Talele, G.S., Surana, S.J. 2012. Antimicrobial activity of an Indiane Mistletoe, the hemiparasite Dendrophthoe falcata L.F.
(Loranthaceae). J. Res. Educ. Indian med., 18(2): 107-111.

Pattanayak, S.P., Sunita, P. 2008. Wound healing, anti-microbial and antioxidant potential of Dendrophthoe falcata (L.f) Ettingsh. J. Ethnopharma., 120: 241247.

Reddy, K. N., Reddy, C. S., Trimurthulu, G. 2006. Ethnobotanical survey on respiratory disorders in eastern ghats of Andhra Pradesh, India. Ethnobot. Leaflets, 10:139-148.

Rothe, S. P. 2003. Ethnomedicinal plants from Katepurna wildlife sanctuary of Akola district. Ind. J. Tradi. Know., 2(4): 38382.

Shanavaskhan, A.E., Sivadasan, M., Alfaran, A..H, Thomas, J. 2012. Ethnomedicinal aspects of angiospermic epiphytes and parasites of Kerala, India. Ind. J. Tradi. Know., 11(2): 250-258.

Singh, R.B., Gupta, P. K. 2013. Morphotaxonomy, medicinal use and new host range of Dendrophthoe falcata var. coccinia in Champaran, its cause and consequences. Ind. J. lif Sci., 2(2) : $39-42$.

Tenpe, C.R., Upaganlawar, A.B., Khairnar, A.U., Yeole, P.G. 2008. Anti-oxidant, anti-hyperlipidaemic and anti-diabetic activity of Dendrophthoe falcata leaves. A preliminary study. Pharm. Mag., 4(16).

Vijigiri, D., Sharma, P. P. 2010. Traditional use of plants in indigenous folklore of Nizamabad district, Andhra Pradeh, India. Ethnobot. Leaflets., 14:29-45.

\section{How to cite this article:}

Anita Jain and Mahima Sharma. 2016. In-vitro Antimicrobial Screening of Dendrophthoe falcata (L.F.) Ettingsh. Int.J.Curr.Microbiol.App.Sci. 5(12): 594-602.

doi: http://dx.doi.org/10.20546/ijcmas.2016.512.064 